\title{
Effect of external solar shading usage on energy consumption and thermal comfort in the student dormitory in Niš
}

\author{
Dragana Krstic ${ }^{1,{ }^{*}, \text { Miomir Vasov }}{ }^{2}$, Veliborka Bogdanović ${ }^{3}$, Marko Ignjatović $^{4}$, and Dušan Ranđelovic ${ }^{5}$ \\ ${ }^{1}$ Faculty of Civil Engineering and Architecture, University of Niš, Serbia \\ ${ }^{2}$ Faculty of Civil Engineering and Architecture, University of Niš ,Serbia \\ ${ }^{3}$ Faculty of Civil Engineering and Architecture, University of Niš ,Serbia \\ ${ }^{4}$ Faculty of Mechanical Engineering, University of Niš ,Serbia \\ ${ }^{5}$ Faculty of Civil Engineering and Architecture, University of Niš ,Serbia
}

\begin{abstract}
External fixed shadings are largely used to provide solar protection for building glazed surfaces. They are reducing heat gains and sensational visual discomfort caused by excessive daylighting. This paper presents a comparative study on external aluminium fixed shadings used on a student dormitory on different orientations and different slat angles. The purpose is to determine which slat angles are best to use in different orientations, from the point of view of energy consumption, thermal comfort, and daylighting. An analysis of annual energy consumption of the student dormitory was performed by using the software EnergyPlus, whereas the model of the building was created using SketchUp and OpenStudio software. Then, a parametric study was carried out by changing slat angles and building orientations, in order to find the best-balanced results with no occupant discomfort and possible energy savings. Results have shown that by considering the most balanced results between energy savings and thermal comfort, the best angles of the slats are from $105^{\circ}$ to $120^{\circ}$ on the south side, and from $45^{\circ}$ to $75^{\circ}$ on the east and west sides. By installing external shading devices, indoor thermal conditions are improving and may lead to significant energy savings, compared to a building without shading devices.
\end{abstract}

\section{Introduction}

Energy, one of the basic inputs for civilization and economic growth [1]. Having this stance in mind, when construction is in question, it is very important to use energy in the right way in order to create optimum conditions for thermal comfort in the interior of the building, while lowering the consumption of energy to a minimum. An increasing change in climatic conditions which is the consequence of global warming, caused by industrialization and high growth of the human population, further highlights the problem of energy consumption as one of the most pressing problems today.

Statistically speaking, approximately $40 \%$ of total global energy consumption is attributed to architectural objects [2]. The forecast made by the EIA predicts that energy consumption in the construction sector will increase by $34 \%$ by the end of 2030 [3]. Energy consumption for HVAC systems, which includes energy for heating, ventilation and air conditioning, has proved to be the most significant in both residential and nonresidential sectors. Since there is a great connection between HVAC power consumption and internal comfort, optimal parameters of the internal comfort are needed for energy savings. However, the connection between HVAC energy consumption and the quality of the internal environment is difficult to determine theoretically because of its dependence on the envelope of the object, the performance of the HVAC system, etc. Therefore, regression analysis and simulation methods have been widely used in parametric studies of energy consumption in buildings [4].

The building envelope plays a very important role in controlling different environmental influences. Adequate building envelope can contribute to reducing harmful environmental impacts by about $80 \%$ [5]. Windows, as a transparent part of the facade, are often perceived as "Achilles heel of facade", as they contribute both to heat losses and to unwanted heat gains [6]. Thus, excessive insolation leads to the overheating of rooms, and, therefore, to the need for their cooling and consumption of energy. On the other hand, if there is insufficient natural laght the usage of artificial lights is enhanced as well as consumption of the electricity. For these reasons, it is necessary to find the optimal solution in order to reduce the use of energy [7]. In order to tackle these negative effects on transparent parts of a building envelope, there are different types of external shading devices that can be used, one of which, mostly used, are aluminium louvers.

The purpose of this research was to determine the optimal angle of external fixed aluminium louvers, under which they should be placed. The research was carried out on the student dormitory, located near technical faculties in Niš. Preceding measurements of internal

\footnotetext{
* Corresponding author: gaga-krstic $@$, live.com
} 
temperatures, carried out in the dormitory which is the subject of this paper, showed very high temperatures that reach $30^{\circ} \mathrm{C}$ during the summer on the south side. That pointed out the fact that it is necessary to get involved in solving that problem so as to accomplish the optimal thermal comfort. The research is based on a comparative analysis of the results obtained by computer simulation containing energy consumption for heating, cooling and lighting. The aim of the paper is to determine the angles of the external horizontal louvers with the help of software simulation (using the EnergyPlus, Sketch up and Open studio package), in which both the optimum light and heat comfort for the students, will be achieved with the lowest possible energy consumption.

\section{External louvers - review of previous research}

Glazed surfaces of a building play an important role when energy consumption is in question. In modern architecture, the use of glazed surfaces is constantly increasing due to the better brightness it gives to the room, as well as a more aesthetic look of the building. However, in this way, demands for greater cooling and room heating are increased [8]. In order to solve these newly emerging problems, the use of façade elements such as shadings and louvers are increasing. They can be placed inside or outside, can be fixed or movable and can be either manual or automatic. When located outside, they are exposed to solar radiation before reaching the interior of the building. Whereas, when they are placed inside, solar radiation is transferred to the glazed space, absorbed, and then radiated again inside causing greater cooling needs [9]. The impact of shadings on energy savings, thermal comfort and lighting, has been researched both experimentally and theoretically [10].

There are numerous studies about different shading systems used on transparent surfaces. Palmero-Marrero and Oliveira wrote about vertical and horizontal brushes with a distance between layers ranging from $0.23 \mathrm{~m}$ to $0.26 \mathrm{~m}$ depending on the different widths [8]. The research results obtained, show that using such a system guarantees internal comfort and energy savings. However, there is also a need for automatic control of louvers in areas with a colder climate in order to avoid high energy consumption. The same results were obtained from a group of researchers from Denmark [11], on a simulation model with the use of small spaces between the louvers $(0.05 \mathrm{~m})$. They demonstrated that the adoption of a dynamic solar shading constitutes the best design alternative. The study pointed out that conflicting aspects of energy need for heating, cooling and artificial lighting should be evaluated simultaneously to identify the best performing façade. Two groups of researchers have conducted a research where they have adopted a high distance between slats, in the hot climate region. The first group - Hammad and Abu-Hijleh [12] from the Arab Emirates used louvers with an axial distance of $0.3 \mathrm{~m}$, and the second group of Alzoubi and Al-Zoubi [13] from Jordan, who used a distance of 0.5 $\mathrm{m}$ between louvers. Both studies had the same ratio between distance and thickness of the slats, close to 1 (to block the sun's rays of $45^{\circ}$ ), and both studies were also focused on variation of the slat angles. Both studies also indicated an increase in energy consumption annually and a reduction in daylighting, by changing the louver's orientation from horizontal to inclined. The same values were adopted by Freewan [14] from England who analysed the optimal configuration of the louvers to increase the daylighting. The authors integrated numerical simulations and experiments on plywood models, emphasizing the importance of the level of illuminance through the room. Within the research, a small distance between slats $(0.05 \mathrm{~m})$ was considered, indicating that the narrow louvers increase the level of illumination near the window and decrease in the distant parts of the room. There has been another research carried out as an analytical study on louvers with different geometries and inclinations, indicating that optimal design depends on location and weather conditions. In cold climates where energy consumption for heating is more important than the energy needed for cooling, windows without screens or louvers were more applied, while the use of louvers (about $60^{\circ}$ angle) was a better solution in areas with warmer climates [15]. The effects of different shading device properties on lighting and cooling in the building were analyzed using external roller shades by researchers Tzempelikos and Athienitis. The results showed that the automated control of motorized shades together with the controlled electrical lighting system caused a significant reduction in energy requirements for cooling and lighting depending on climatic conditions and orientation [16]. In another study on a building in Malaga, there were solutions proposed to reduce solar gain by installing fixed louvers, horizontal on the south facade and vertical on the eastern facade. Analyzing the effect on cooling energy consumption, it has been concluded that horizontal louvers in the south make savings of $68 \%$ compared to the underlying case. Also, it was noticed that the angles of 60 (north) and -60 (south) are more effective in reducing cooling requirements, but they therefore negatively affect the consumption of lighting energy. The study has proven that angles of 30 and -30 are better solutions because they provide a better balance between cooling energy consumption, lighting, and visual comfort [17].

\section{Methodology}

\subsection{Object and model description}

The analysed student dormitory (Pavilion 4) is located in Niš, near the technical faculties. In terms of architectural features, the student dormitory is a free-standing building that has eleven floors besides the ground floor. The floors of the dormitory are all the same like in Figure 1, except the third floor where the common rooms for the students are located. The dormitory is rotated for $33^{\circ}$ related to the north, counterclockwise. On each of the 
eastern, southern and western side, there are four double

\section{OCHOBA TIPSKOG CIPATA}

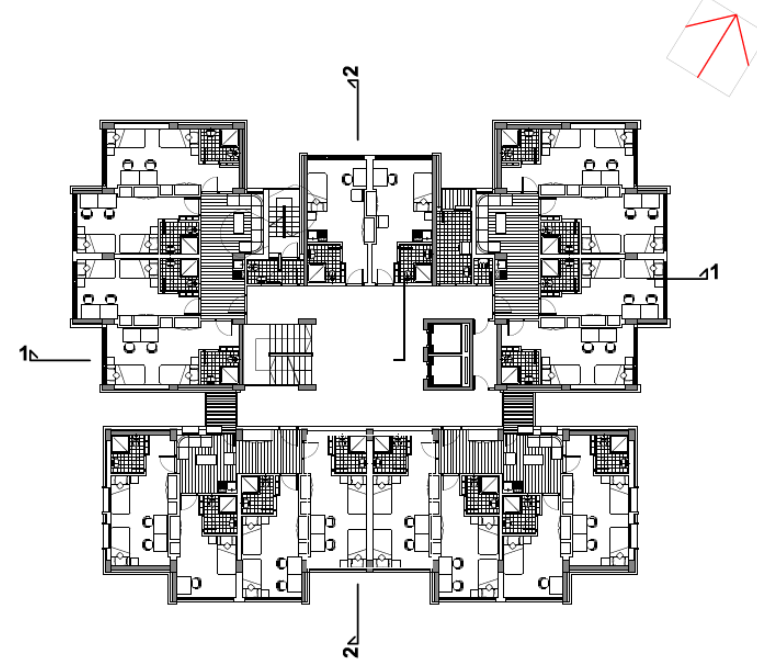

Fig. 1. Floor plan of the student dormitory.

rooms with a single dining area and a mini kitchen. On the north side there are two single rooms with separate mini kitchens. Materialization of the façade is in the facade brick and the finishing plaster. The rooms are illuminated with windows as wide as the room itself, with total area of $4.38 \mathrm{~m}^{2}$, the exception are two corner rooms with side windows, with area of $3.9 \mathrm{~m}^{2}$.

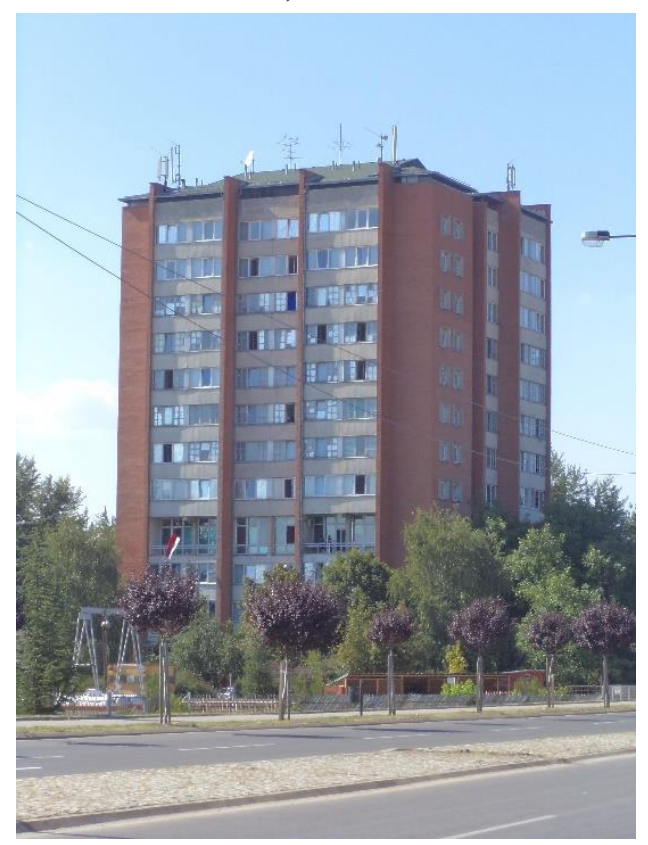

Fig. 2. The building of student dormitory.

\subsection{Climate}

Analysed dormitory is located in the city of Nis, in the state of Serbia. The city has the average height above the sea level $202 \mathrm{~m}$. Its latitude is $43^{\circ} 19^{\prime} \mathrm{N}$, longitude $21^{\circ} 54^{\prime} \mathrm{E}$, and time zone GMT $+1.0 \mathrm{~h}$. Nis has a moderate continental climate, with a change of four seasons (winter, spring, summer, and autumn) and average temperature of $11.9{ }^{\circ} \mathrm{C}$. The hottest month is July with an average temperature of $20.4{ }^{\circ} \mathrm{C}$, and the coldest January with a mean temperature of $0.6{ }^{\circ} \mathrm{C}$. Annually, on average $580.3 \mathrm{~mm}$ of rain and snow falls per square meter, and there is averagely 134 rainy days and 37 days with snow [18]. The average air pressure is 992.74 millibars, and the average wind strength is slightly less than 3 beaufort. The maximum ever recorded temperature was $44.2{ }^{\circ} \mathrm{C}$ July 24.2007 . and the lowest $-23.7^{\circ} \mathrm{C}$ on January 25. 1963.

The period between 1990 and 2010 (except in 2008), was the period with the average annual insulation for the city of Niš with $1997.7 \mathrm{~h}$. The largest number of hours of insolation is in June, July and August, with a monthly insolation value, above $250 \mathrm{~h}$. The smallest insolation is in December with an average value of $51.2 \mathrm{~h}$ per month.

\subsection{Simulation method}

In this paper, EnergyPlus software package was used to determine the energy consumption of the student dormitory. Namely, the student pavilion in the given research was evaluated in terms of energy consumption after changes on the façade such as application of external fixed louvers, whose angle was rotated. A total of 12 different positions of aluminium louvers, on south, east and west sides, are rotated. The geometry of the model was originally made in Google Sketch Up program using OpenStudio plug-in program. EnergyPlus was used to simulate heating, cooling and electricity. This software can model energy consumption in residential buildings [19]. EnergyPlus takes into account all factors that influence thermal changes in the building, such as: electrical appliances, lighting, building pipes, solar radiation, wind, infiltration and room shading. This software allows designers to simulate the behavior of energy for residential buildings for chosen period, and propose some ways for energy saving. EnergyPlus has already been used to study the positive net energy of housing in Serbia by Bojic [20]. Also, the program was also used for multistory buildings in the same climatic conditions like in Serbia [7].

As the aim of the work is to show the best angle of the external fixed louvers on the southern, eastern and western side, the $3 \mathrm{~d}$ model of the entire student dormitory is made. The floors from the first to the eleventh are modeled all the same with 12 thermal zones that represent rooms and one thermal zone that contains all the hallways. Each floor has 13 thermal areas. Only the ground floor is modeled with different thermal zones. In the computer simulation, the ideal internal temperature was adopted, during the summer $26{ }^{\circ} \mathrm{C}$ and during the winter $22^{\circ} \mathrm{C}$. Ideal HVAC system has been adopted to cover the needs of all thermal areas. In the EnergyPlus software package, the weather file for the Nis area was used, according to which external temperatures were used. The weather data contains data for the critical elements needed for simulation at the hourly level (relative humidity, air temperature, barometric pressure, direct normal radiation, diffuse horizontal radiation, velocity and wind direction ..), as well as data on snow or rain that can serve in certain situations [7]. 
Table 1. The main constructions used in the project.

\begin{tabular}{|c|c|c|c|c|c|c|}
\hline Construction & Layer 1 & Layer 2 & Layer 3 & Layer 4 & Layer 5 & Layer 6 \\
\hline \multirow[t]{3}{*}{$\begin{array}{l}\text { Exterior } \\
\text { wall }\end{array}$} & $\begin{array}{l}\text { Brick } \\
\mathrm{d}=12 \mathrm{~cm} \\
\lambda=0.52 \mathrm{~W} / \mathrm{mK}\end{array}$ & $\begin{array}{l}\text { Polystyrene } \\
\mathrm{d}=2 \mathrm{~cm} \\
\lambda=0.041 \mathrm{~W} / \\
\mathrm{mK}\end{array}$ & $\begin{array}{l}\text { Brick blok } \\
\mathrm{d}=25 \mathrm{~cm} \\
\lambda=0.61 \mathrm{~W} / \mathrm{mK}\end{array}$ & $\begin{array}{l}\text { Lime mortar } \\
\mathrm{d}=1.5 \mathrm{~cm} \\
\lambda=0.87 \mathrm{~W} / \mathrm{mK}\end{array}$ & & \\
\hline & $\begin{array}{l}\text { Brick } \\
\mathrm{d}=12 \mathrm{~cm} \\
\lambda=0.52 \mathrm{~W} / \mathrm{mK}\end{array}$ & $\begin{array}{l}\text { Closed air } \\
\mathrm{d}=5 \mathrm{~cm}\end{array}$ & $\begin{array}{l}\text { Polystyrene } \\
\mathrm{d}=2 \mathrm{~cm} \\
\lambda=0.041 \mathrm{~W} / \mathrm{mK}\end{array}$ & $\begin{array}{l}\text { Reinforced } \\
\text { concrete } \\
d=15 \mathrm{~cm} \\
\lambda=2.2 \mathrm{~W} / \mathrm{mK}\end{array}$ & $\begin{array}{l}\text { Extended } \\
\text { mortar } \\
d=1.5 \mathrm{~cm} \\
\lambda=0.99 \mathrm{~W} / \mathrm{mK}\end{array}$ & \\
\hline & $\begin{array}{l}\text { Extended } \\
\text { mortar } \\
\mathrm{d}=1.5 \mathrm{~cm} \\
\lambda=0.99 \mathrm{~W} / \mathrm{mK}\end{array}$ & $\begin{array}{l}\text { Polystyrene } \\
\mathrm{d}=2 \mathrm{~cm} \\
\lambda=0.041 \mathrm{~W} / \\
\mathrm{mK}\end{array}$ & $\begin{array}{l}\text { Brick blok } \\
\mathrm{d}=25 \mathrm{~cm} \\
\lambda=0.61 \mathrm{~W} / \mathrm{mK}\end{array}$ & $\begin{array}{l}\text { Lime mortar } \\
\mathrm{d}=1.5 \mathrm{~cm} \\
\lambda=0.87 \mathrm{~W} / \mathrm{mK}\end{array}$ & & \\
\hline $\begin{array}{l}\text { Floor } \\
\text { construction }\end{array}$ & $\begin{array}{l}\text { Extended } \\
\text { mortar } \\
\mathrm{d}=1.5 \mathrm{~cm} \\
\lambda=0.99 \mathrm{~W} / \mathrm{mK}\end{array}$ & $\begin{array}{l}\text { Polystyrene } \\
d=1 \mathrm{~cm} \\
\lambda=0.041 \\
W / \mathrm{mK}\end{array}$ & $\begin{array}{l}\text { Reinforced } \\
\text { concrete } \\
d=20 \mathrm{~cm} \\
\lambda=2.2 \mathrm{~W} / \mathrm{mK}\end{array}$ & $\begin{array}{l}\text { Elasticized } \\
\text { styrofoam } \\
d=2 \mathrm{~cm} \\
\lambda=0.041 \mathrm{~W} / \mathrm{mK}\end{array}$ & $\begin{array}{l}\text { Cement screed } \\
\mathrm{d}=4 \mathrm{~cm} \\
\lambda=1.4 \mathrm{~W} / \mathrm{mK}\end{array}$ & $\begin{array}{l}\text { Parquet } \\
\mathrm{d}=2.2 \mathrm{~cm} \\
\lambda=0.21 \\
W / \mathrm{mK}\end{array}$ \\
\hline Flat roof & $\begin{array}{l}\text { Gravel } \\
\mathrm{d}=6 \mathrm{~cm} \\
\lambda=0.81 \mathrm{~W} / \mathrm{mK}\end{array}$ & $\begin{array}{l}\text { Polystyrene } \\
\mathrm{d}=8 \mathrm{~cm} \\
\lambda=0.041 \\
W / \mathrm{mK}\end{array}$ & $\begin{array}{l}\text { Slag concrete } \\
\mathrm{d}=4 \mathrm{~cm} \\
\lambda=0.76 \mathrm{~W} / \mathrm{mK}\end{array}$ & $\begin{array}{l}\text { Reinforced } \\
\text { concrete } \\
d=20 \mathrm{~cm} \\
\lambda=2.2 \mathrm{~W} / \mathrm{mK}\end{array}$ & $\begin{array}{l}\text { Extended } \\
\text { mortar } \\
d=1.5 \mathrm{~cm} \\
\lambda=0.99 \mathrm{~W} / \mathrm{mK}\end{array}$ & \\
\hline
\end{tabular}

Table 2. Construction surfaces and their U coeficients.

\begin{tabular}{|c|c|c|c|c|c|}
\hline $\begin{array}{c}\text { Exterior } \\
\text { construction }\end{array}$ & SZ1 & SZ2 & SZ3 & RK1 & P1 \\
\hline $\begin{array}{c}\mathrm{U} \text { coeficient } \\
\left(\mathrm{W} / \mathrm{m}^{2} \mathrm{~K}\right)\end{array}$ & 0.779 & 0.825 & 0.936 & 0.438 & 2.703 \\
\hline $\begin{array}{c}\text { Construction } \\
\text { surface }\left(\mathrm{m}^{2}\right)\end{array}$ & 1255.365 & 1367.04 & 1125.158 & 593.76 & 1150,92 \\
\hline
\end{tabular}

The building has facade insulation of $2 \mathrm{~cm}$. Window frames are made of PVC with two-layer float glass (412-4). The main envelope constructions used in the project are given in Table 1, and their surfaces and $\mathrm{U}$ coeficients in Table 2.

In the student dorm rooms, the basic activities are learning, drawing and writing, so in the simulation it has been accepted that within each thermal zone the minimum light intensity is 250 lux. In order to achieve the set parameters, in the program it is set to automatically switch on artificial lighting in every thermal zone in case of lack of daylight. In EnergyPlus program, the lighting schedule (which defines the percentage of available light power) is adjusted depending on the time of the day, in order to provide a more realistic display of electricity consumption for lighting. Besides, in OpenStudio software there has been set "Daylighting: Controls" in each of Thermal Zones and placed at $80 \mathrm{~cm}$ height from the floor. In the simulation this enables artificial lighting to be turned on in case of lack of natural light. A heat meters are created and used to measure annual heat consumption in all zones.

To obtain the final results of the simulation process, jEPlus program, a batch shell for parametric studies, was used in the research. jEPlus is a open source tool specially developed for complex parametric simulations using the EnergyPlus program [21].

One parameter is chosen for variations, which is the position of angle of external fixed louvers. The angles to which the simulation is set are: 0 , $15^{\circ}, 30^{\circ}, 45^{\circ}, 60^{\circ}$, $75^{\circ}, 90^{\circ}, 105^{\circ}, 120^{\circ}, 135^{\circ}, 150^{\circ}, 165^{\circ}$.

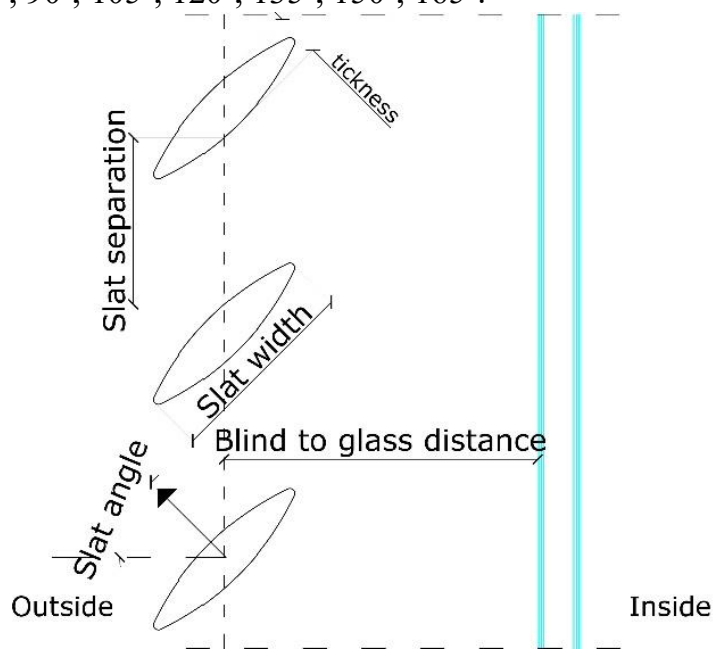

Fig. 3. Geometry characteristics of aluminium louvers

The analysed louvers are hollow profiles of aluminium, $10 \mathrm{~cm}$ wide, and $2.5 \mathrm{~cm}$ thick. They are placed over the entire surface of the window. Distance of the axis of the louvers from the outer surface of the window is $16 \mathrm{~cm}$, while the height distance from one slat to the other is $8.5 \mathrm{~cm}$.

\section{Results and discussion}

In total, 1728 simulations of annual energy consumption were performed for the whole student dormitory, 12

\footnotetext{
* Corresponding author: gaga-krstic@live.com
} 


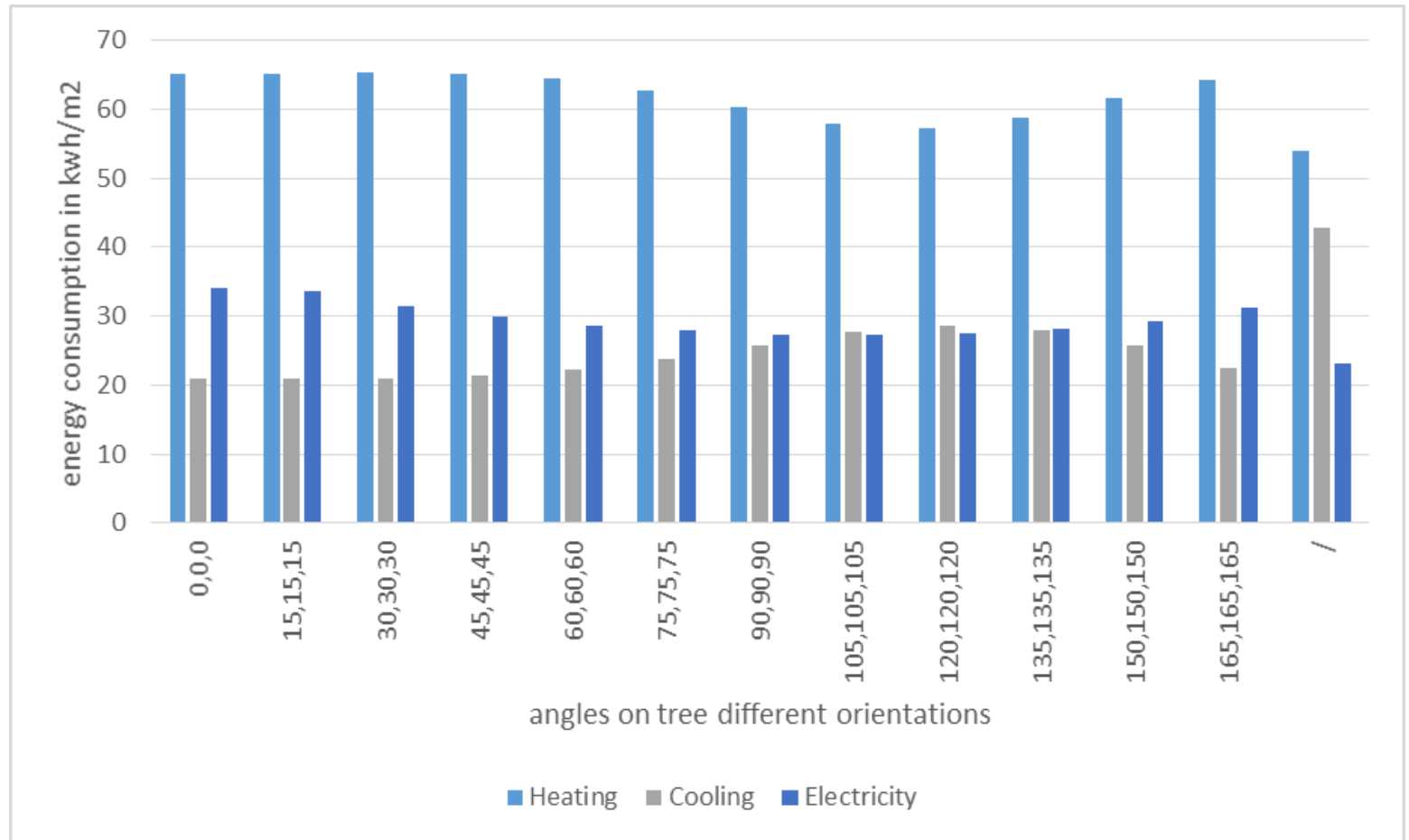

Fig. 4. Annual energy consumption for different angles different positions of louvers on 3 different orientations. The simulations give the values of the total annual energy consumption for heating, cooling and electricity, where they are shown on Figure 4 in Kwh / $\mathrm{m} 2$ of the heated space of the student home, which has a total of $6164 \mathrm{~m}^{2}$ of heated space.

In the first iteration, an overview of energy consumption was performed when the angles on the southern, eastern and western sides were the same, showing 12 variants, with one more variant without louvers. The results are shown in Figure

Based on the results it is concluded that the minimum energy consumption for heating in the case where the angle of the louver is $120^{\circ}$, for cooling purposes when the angle is $15^{\circ}$ for the lighting energy with an angle of $105^{\circ}$. If we compare these results with a basic model where there are no louvers, we see that heating energy and electricity for lighting are smaller in base case without louvers, while the cooling energy is much higher. The best variant in which there is a good balance of energy for heating, cooling and lighting is with angle of louvers $105^{\circ}$. For such a position, the annual energy

Table 4. Chosen variants with best energy balance consumption for heating is $58.03 \mathrm{KWh} / \mathrm{m}^{2}$, for cooling 27.68 KWh/ $\mathrm{m}^{2}$, and for lighting $27.27 \mathrm{KWh} / \mathrm{m}^{2}$. It can be concluded that the heating energy is $7.30 \%$ higher, the lighting energy is $19.96 \%$ higher, while the cooling energy is lower by $35.42 \%$ compared to the base case. Moreover, in one of the previous research for the same student dormitory, the authors came to the conclusion that thermal comfort is deteriorating considerably in the summer period when the influence of solar energy is stronger [22].

In the further analysis, different angles were compared on different orientations.

Of all of 1728 variants, 8 combinations were selected in which the best balance of energy consumption was achieved. An overview of the selected variants is given in Table 4.

From the previous Figure, it can be concluded that the best position of louvers on the south side is at angles from $105^{\circ}$ to $120^{\circ}$, while on the eastern and western sides it ranges from $45^{\circ}$ to $75^{\circ}$. In Figure 5, it can be noted that, for cooling energy consumption, the position of louvers is better at an angle of $105^{\circ}$ in the south, $45^{\circ}$ in the east and $60^{\circ}$ in the west. Lighting is somewhat better when the positions of the angles of the louvers are

\begin{tabular}{|r|r|r|r|r|l|l|l|l|l|}
\hline & \multicolumn{4}{|c|}{ Angles } & \multicolumn{3}{|c|}{ Energy consumption in Kwh } & \multicolumn{3}{c|}{ Energy consumption in Kwh/m ${ }^{2}$} \\
\hline Num. & South & East & West & Heating & Cooling & Electricity & Heating & Cooling & Electricity \\
\hline 1 & 105 & 45 & 60 & 371388.8884 & 140956.66 & 176348.44 & 60.25128 & 22.867725 & 28.6094159 \\
\hline 2 & 105 & 45 & 75 & 369428.1386 & 144095.71 & 174464.54 & 59.93318 & 23.376982 & 28.3037871 \\
\hline 3 & 105 & 60 & 45 & 371485.7118 & 141360.03 & 176978.15 & 60.26699 & 22.933165 & 28.7115755 \\
\hline 4 & 105 & 60 & 60 & 370426.277 & 143241.11 & 174162.91 & 60.09511 & 23.238337 & 28.2548518 \\
\hline 5 & 105 & 75 & 45 & 369836.6521 & 144959.71 & 175502.7 & 59.99946 & 23.517149 & 28.4722091 \\
\hline 6 & 120 & 45 & 60 & 366838.216 & 142276.6 & 176591.21 & 59.51301 & 23.081863 & 28.6488003 \\
\hline 7 & 120 & 60 & 45 & 366936.0985 & 142682.25 & 177220.92 & 59.52889 & 23.147671 & 28.7509599 \\
\hline 8 & 120 & 60 & 60 & 365888.5979 & 144575.11 & 174405.67 & 59.35895 & 23.454754 & 28.2942362 \\
\hline
\end{tabular}


such that it is $105^{\circ}$ in the south, $60^{\circ}$ in the east and $60^{\circ}$ in the west. When heating is in question a better option, is with a louver angle of $120^{\circ}$ in the south, and $60^{\circ}$ in the east and west. Now, the heating energy consumption is $10.05 \%$ higher than the in the base case, the lighting energy is $24.17 \%$ higher, and cooling energy is $46.14 \%$ lower than the variant without louvers. The proposed changes on the facade considerably reduce thermal gains, which clearly indicates the possible way of solving the problem of thermal overheating during the summer.

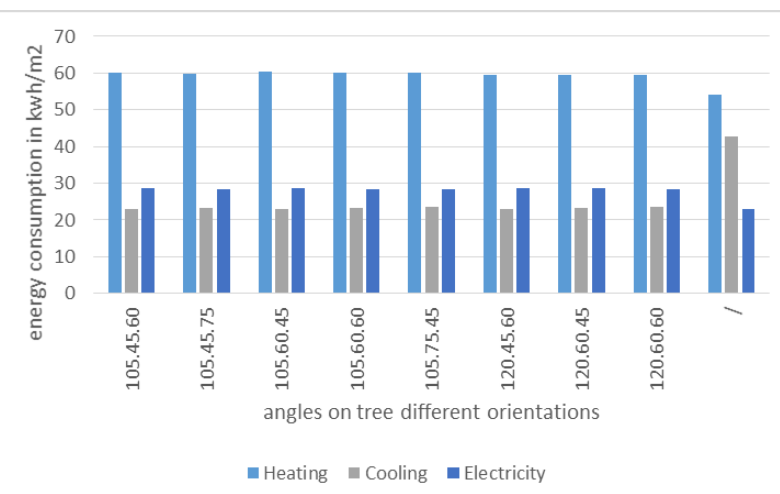

Fig. 5. Variants with best balance in energy consumption

After the above mentioned numerical simulations, in further analysis 1331 simulations were made for each of the three characteristic months in the period of summer and winter (June, July, August, December, January and February), in order to, even more precisely, determine the most suitable angle of external louvers in summer and winter periods. In these simulations, the narrower range of external louver angles was selected. From $45^{\circ}$ to $75^{\circ}$ and from $105^{\circ}$ to $120^{\circ}$ with an incremental step of $5^{\circ}$.

Table 5. Chosen variants with best energy balance in December.

\begin{tabular}{|c|c|c|c|c|c|}
\hline Num. & \multicolumn{3}{|c|}{ Angles } & \multicolumn{2}{c|}{$\begin{array}{c}\text { Energy consumption } \\
\text { in Kwh/m }\end{array}$} \\
\hline & South & East & West & Heating & Electricity \\
\hline 1 & 110 & 105 & 105 & 14.1342 & 2.589747 \\
\hline 2 & 110 & 105 & 110 & 14.12652 & 2.590498 \\
\hline 3 & 110 & 105 & 115 & 14.12419 & 2.592032 \\
\hline 4 & 110 & 110 & 105 & 14.12774 & 2.590602 \\
\hline 5 & 110 & 110 & 110 & 14.12006 & 2.591353 \\
\hline
\end{tabular}

Table 6. Chosen variants with best energy balance in January.

\begin{tabular}{|r|r|r|r|r|r|}
\hline Num. & \multicolumn{3}{|c|}{ Angles } & \multicolumn{2}{c|}{$\begin{array}{c}\text { Energy consumption } \\
\text { in Kwh/m }{ }^{2}\end{array}$} \\
\hline & South & East & West & Heating & Electricity \\
\hline 1 & 110 & 115 & 110 & 15.17567 & 2.581564 \\
\hline 2 & 115 & 105 & 105 & 15.16596 & 2.578817 \\
\hline 3 & 115 & 105 & 110 & 15.15842 & 2.579649 \\
\hline 4 & 115 & 110 & 105 & 15.15687 & 2.579933 \\
\hline 5 & 115 & 110 & 110 & 15.14933 & 2.580765 \\
\hline
\end{tabular}

Table 7. Chosen variants with best energy balance in February.

\begin{tabular}{|r|r|r|r|r|r|}
\hline Num. & \multicolumn{3}{|c|}{ Angles } & \multicolumn{2}{c|}{$\begin{array}{c}\text { Energy consumption } \\
\text { in Kwh/m }\end{array}$} \\
\hline & South & East & West & Heating & Electricity \\
\hline 1 & 120 & 105 & 105 & 12.42366 & 2.475233 \\
\hline 2 & 120 & 105 & 110 & 12.40961 & 2.476621 \\
\hline 3 & 120 & 110 & 105 & 12.41192 & 2.476811 \\
\hline 4 & 120 & 110 & 110 & 12.3979 & 2.478198 \\
\hline 5 & 115 & 110 & 110 & 12.46011 & 2.477509 \\
\hline
\end{tabular}

Table 8. Chosen variants with best energy balance in June.

\begin{tabular}{|r|r|r|r|r|r|}
\hline Num. & \multicolumn{4}{|c|}{ Angles } & \multicolumn{2}{|c|}{$\begin{array}{c}\text { Energy consumption in } \\
\text { Kwh/m }\end{array}$} \\
\hline & South & East & \multicolumn{1}{c|}{ West } & Cooling & Electricity \\
\hline 1 & 70 & 70 & 75 & 5.094313 & 2.1362909 \\
\hline 2 & 70 & 75 & 70 & 5.094355 & 2.1379368 \\
\hline 3 & 75 & 65 & 75 & 5.071778 & 2.1385948 \\
\hline 4 & 75 & 70 & 70 & 5.06573 & 2.1383655 \\
\hline 5 & 75 & 75 & 65 & 5.063678 & 2.1410578 \\
\hline
\end{tabular}

Table 9. Chosen variants with best energy balance in July.

\begin{tabular}{|r|r|r|r|r|r|}
\hline Num. & \multicolumn{4}{|c|}{ Angles } & \multicolumn{2}{|c|}{$\begin{array}{r}\text { Energy consumption in } \\
\text { Kwh/m }{ }^{2}\end{array}$} \\
\hline & South & \multicolumn{1}{|c|}{ East } & \multicolumn{1}{c|}{ West } & Cooling & Electricity \\
\hline 1 & 70 & 65 & 75 & 7.29142 & 2.062978 \\
\hline 2 & 70 & 70 & 70 & 7.292608 & 2.064204 \\
\hline 3 & 75 & 65 & 75 & 7.31196 & 2.058546 \\
\hline 4 & 75 & 70 & 70 & 7.313157 & 2.059772 \\
\hline 5 & 115 & 65 & 70 & 7.303511 & 2.062996 \\
\hline
\end{tabular}

Table 10. Chosen variants with best energy balance in August.

\begin{tabular}{|r|r|r|r|c|c|}
\hline Num. & \multicolumn{4}{|c|}{ Angles } & \multicolumn{2}{c|}{$\begin{array}{c}\text { Energy consumption in } \\
\text { Kwh } / \mathrm{m}^{2}\end{array}$} \\
\hline & South & \multicolumn{1}{|c|}{ East } & West & Cooling & Electricity \\
\hline 1 & 60 & 75 & 75 & 7.456304 & 2.21311437 \\
\hline 2 & 65 & 70 & 75 & 7.426195 & 2.21271648 \\
\hline 3 & 70 & 70 & 75 & 7.464144 & 2.20701594 \\
\hline 4 & 75 & 65 & 75 & 7.439058 & 2.21085743 \\
\hline 5 & 75 & 70 & 70 & 7.446102 & 2.21363929 \\
\hline
\end{tabular}

In each of 6 performed simulations, 5 values were selected with the lowest energy consumption for heating and cooling, or cooling and Electricity, given in the tables above.

The tables show that in the winter period, when there is no need for cooling, the best position of external fixed louvers is at an angle of $110^{\circ}$ on the south side, for December, $115^{\circ}$ for January and $120^{\circ}$ for February. On the east and west sides, this angle varies from $110^{\circ}$ to $115^{\circ}$ in all three months. In contrast to the winter period in the summer period, the most optimal angle on the south side is in the range of $65^{\circ}$ to $75^{\circ}$, as well as on the west and east side.

\section{Conclusion}

In this paper, an annual energy consumption analysis was conducted in the student dormitory, using the 
EnergyPlus software package. Annual energy consumption has also been carried out after architectural changes on the façade, such as the installation of exterior fixed louvers. Based on the results, it is concluded that significant energy savings in terms of cooling energy can be achieved by setting louvers, especially if their position on the south side is from an angle of $105^{\circ}$ to $120^{\circ}$ and on the east and west sides at an angle of $45^{\circ}$ to $75^{\circ}$. Furthermore, the research showed that during the winter the most favorable position for the louvers is at an angle of about $110^{\circ}$, while in the summer period a more favorable angle is about $70^{\circ}$. Setting louvers also affects the increase in energy for lighting and heating, but this energy is less than the savings made by the reduced cooling requirement. In addition, the proposed changes to the facade can significantly improve the working environment for students in the dormitory, in the form of better thermal comfort and productivity.

The research carried out in this paper can contribute to the improvement of the student's current state in terms of energy savings and the achievement of thermal comfort. Also, this research can help architects when designing new objects of this type, or as a basis for similar research conducted on objects of another type.

\section{References}

1. J. Kuntal, A. Ray, M. Mnasouri Majoumerd, M. Addadi, S. De, Applied energy, 202, 88-111 (2014)

2. A.M. Omer, Renewable and Sustainable Energy Reviews, 12, 2265-2300 (2008)

3. Energy information Administration, "International Energy Outlook, " U.S. Department of Energy, (2006)

4. C. Dai, L. Lan, Z. Lian, Energy and Buildings, 76, 278-283 (2014)

5. D.A. Chi, D. Moreno, J. Navarro, Building and Environment, 125, 383-400 (2017)

6. A. Vlachokostas, N. Madamopoulos, Building and Environment, 126, 396-4009 (2017)

7. P. Pejić, D. Petković, S. Krasić, Thermal Science, 18, 979-988 (2014)

8. A. I. Palmero-Marrero, A. C. Oliveira, Applied Energy, 87, 2040-2049, (2010)

9. D. Ouahrani, A. Al Touma, Energy \& Buildings, 165, 440-450 (2018)

10. F. Stazi, S. Marinelli, C. Di Perna, P. Munafo, Solar Energy, 105, 512-528 (2014)

11. M. V. Nielsen, S. Svendsen, L. M. Bjerregaard Jensen, Solar Energy, 85, 757-768, (2011)

12. F. Hammad, B. Abu-Hijleh, Energy and Buildings, 42, 1888-1895 (2010)

13. H.H. Alzoubi, A.H. Al-Zoubi, Energy Conversion and Management, 51, 1592-1599, (2010)

14. A. Freewan, L. Shao, S. Riffat, Renewable Energy, 34, 223-232 (2009)

15. G. Datta, Renewable Energy, 23, 497-507, (2001)

16. A. Tzempelikos, A.K. Athienitis, Solar Energy, 81, 369-382 (2007)

17. F. Fernandez Hernandez, J. M. Cejudo Lopez, J.M.
Pena Suarez, M.C. Gonzalez Mauriano, S. Carrillo Rueda, Energy Procedia, 140, 207-216 (2017)

18. "http://www.hidmet.gov.rs/eng/meteorologija/stani ca_sr.php?moss_id=13388," Republic Hidrometeorological Service of Serbia.

19. J. Teshome Edae, Energy and buildings, 73, 171175 (2014)

20. M. Bojić, N. Nikolić, D. Nikolić, J. Skerlić, I. Miletić, Applied Energy, 88, 2407-2419 (2011)

21. Y. Zhang, I. Korolija, "Performing complex parametric simulations with jEPlus," in SET2010 9th International Conference on Sustainable Energy Technologies, Shanghai (2010)

22. A. Jovanović, P.Pejić, S. Veljković Đorić, J. Karamarković, M.Đelić, Energy and Buildings, 77, 158-170 (2014) 